\title{
Closing the Gender Gap?: New Spaces of Cultural Memory Construction for Contemporary Female Authors in Portugal
}

\author{
Suzan Bozkurt \\ University of Manchester
}

\begin{abstract}
This study is an exploration of feminist and non-essentialist, universal memory spaces for contemporary female authors in Portugal. It is based on the representations of four writers, Hélia Correia, Teolinda Gersão, Lídia Jorge and Inês Pedrosa in academic, press and online criticism. This study shows how a national critical language that re-enforces gender normativity in categorizations that often only leave the outside position of 'escrita feminina' to the majority of contemporary authors is counter-acted in a world literary space, where women writers' work is judged and valued through other ideological and socio-cultural lenses that make the emergence of different and differing 'regimes of value' possible. Press and online critical localities represent a more flexible, fluid and multi-faceted space, where critical contextualizations are constantly overwritten, preventing static categories that can then be 'naturalized'. Authors themselves can influence press and online critical commentary in performative acts as well as through the creation of an authorial 'online self', which creates a counter-memory to the traditional contextualizations in a national field that follow normative constructions rooted in a patriarchal discourse. On the one hand, a traditional elitist critical approach can be observed in all media, academic, press and, digital, that often misreads and omits women's literary projects. On the other hand, female and feminist spaces of alternative constructions of cultural memory are also present and traditional contextualizations co-exist with new classificatory mechanisms that give a more adequate representation to contemporary female authorship.
\end{abstract}

Keywords: gender criticism, cultural memory construction, authorial representations in academic/press/online media 
Resumo: Este estudo reflete sobre espaços de memória universais, feministas e não-essencialistas encontrados em autoras portuguesas contemporâneas, centrando-se nas representações de quatro escritoras - Hélia Correia, Teolinda Gersão, Lídia Jorge e Inês Pedrosa - encontradas na crítica académica, de imprensa e online. Pretende-se mostrar como à linguagem da crítica nacional, que reforça a normatividade de género e relega a maioria das autoras contemporâneas para a categoria marginal de "escrita feminina", se contrapõe a linguagem do espaço literário mundial, no qual o trabalho das mesmas escritoras é recebido e valorizado através de lentes ideológicas e socioculturais que permitem o aparecimento de 'regimes de valor' diferentes e variáveis. A crítica de imprensa e a crítica online representam um espaço mais flexível, fluido e multifacetado, onde as contextualizações críticas são constantemente substituídas, evitando-se categorias estáticas e a sua "naturalização". As próprias autoras podem influenciar o comentário crítico produzido na imprensa e online através de atos performativos ou da criação de um "on-line self" autoral, criando uma contra-memória relativamente às contextualizações tradicionais feitas a nível nacional e que seguem construções normativas enraizadas num discurso patriarcal. Por um lado, encontramos uma abordagem crítica tradicional e elitista nos diversos meios de comunicação (académicos, de imprensa e digital), que frequentemente tresleem ou omitem projetos literários femininos. Por outro lado, encontramos também espaços femininos e feministas que apresentam construções alternativas de memória cultural, de modo que as contextualizações tradicionais coexistem com novos mecanismos classificatórios que permitem uma representação mais adequada da autoria contemporânea feminina.

Palavras-chave: crítica de género, construção de memória cultural, representações autorais em media académica / imprensa / meios de comunicação online

In this analysis a search for new localities of a feminist ${ }^{1}$ and a non-essentialist, universal female cultural memory looks at the literary landscape in Portugal at the turn of the $21^{\text {st }}$ century and examines the critical reception of texts published by female authors. On the one hand, traditional mechanisms of constructions of cultural value still persist in Portugal in a cultural criticism that only offers fixed positions to women authors in a static literary field, but, on the other hand, an alternative or counter-memory is also visible in hybrid and transnational memory spaces. The study focuses on the reception of four contemporary female authors, Hélia Correia, Teolinda Gersão, Lídia Jorge and Inês Pedrosa, in academic literary criticism, the press and digital media such as social media, websites 
and wikis. Although an elitist approach to canon formation and constructions of literary prestige can often be observed, in academic, press and online criticism, more multi-faceted memory spaces are also visible outside the constrictions and limitations of the national field of cultural criticism. Once women authors move out of a national critical context and enter a world literary space, new critical spaces become available to them and the potential inherent in the ideological transgression as well as the innovative creativity present in the variety of genres women writers use, is unlocked. Global forces that come into play particularly in press and online critical contextualizations, can lead to innovative 'regimes of value' (see Frow 1995: 151), that transgress such limiting categorizations as 'popular' and 'quality' literary production, and authors themselves can now, in 21 $1^{\text {st-century digital }}$ media society, construct a 'public self', through performative acts ${ }^{2}$ in press interventions or a participation in social media, blogs and websites. These critical spaces are localities of hybridity and transition, characterized by a transnational approach that transcends the national cultural field in an opening up of critical positions into different and differing mechanisms of cultural memory construction.

\section{Memory Construction in a Traditionalist National Field vs. Global Memory Spaces}

Literary prestige and the construction of a national canon is intrinsically tied to the critical language that is used to describe and categorize an author's literary projects. As Ana Gabriela Macedo and Ana Luísa Amaral state in their Introdução ao Dicionário Terminológico de Conceitos da Crítica Feminista, "é também da escolha de palavras que aqui nos ocupamos, tal como dos seus sentidos, tantas vezes fluidos" (Macedo/Amaral 2002: 384). Hélia Correia, Teolinda Gersão, Lídia Jorge and Inês Pedrosa all enjoy some canonical recognition through the traditional means of literary consecration, though to a varying degree. Their names are mentioned in literary histories, such as Carlos Reis' História Crítica da Literatura Portuguesa (2006), the História da Literatura Portuguesa, edited by Óscar Lopes and Maria de Fátima Marinho (2002), and Fernando Pinto do Amaral's 100 Livros Portugueses do Século XX (2002), but, apart from Lídia Jorge, they are seldom included into the main narratives represented in literary histories. Even if their work is mentioned, the 
categorizations employed prevent any adequate contextualizations that would truly represent the text's gender critical content. Judith Butler observes in Gender Trouble that "representation serves as the operative term within a political process that seeks to extend visibility and legitimacy to women as political subjects; on the other hand, representation is the normative function of language which is said either to reveal or to distort what is true about the category of women" (Butler 2007: 2). Although the names of women writers can be found in the nation's literary histories, an essentialist categorization of their writing and a lack of generational contextualization only offer very limited positions to female authorship.

In the Portuguese cultural field an elitist approach to critical discourse is prevalent, where critical authority is granted to the 'educated' or 'distinguished' critic, who, by his/her professional standing as academic or journalist has earned the right to decide which texts are worthy to be included into the canon. These decisions represent an uncontested critical terrain and, over time, become 'natural'. In Portugal this elitist critical approach has persisted into the $21^{\text {st }}$ century, as a strong political orientation of the literary establishment is still in place and remains as a relict from authoritarian control (see Rendeiro 2007: 143, 107), and it is a small and select circle of critics that makes decisions on the prestige of author and text. Literary historians with national reputations form part of this group and therefore traditional categories of criticism seem immutable. Female authorship, in such traditionalist environments, is either side-lined or misinterpreted and misread. If female authors acquire 'quasi-maleness' in being included into a canon, where any universal literary expression is deemed to be male, they do so as 'exceptional examples', while all other literary production by women writers is subsumed into the essentialist category of 'escrita feminina'. Scholars such as Chatarina Edfeldt (2006: 107), Hilary Owen and Cláudia Pazos Alonso (2011: 17), Ana Luísa Amaral and Maria Irene Ramalho de Sousa Santos (1997: 3) point to and firmly reject such a textualization process guided by an essentialist view of female authorship, where the term 'escrita feminina' or 'a autoria feminina' demarcates the lines of a discourse of dissent or otherness within the structures of a malecentred canon. Most women writers are thus represented in a gendered category apart 
from the main canon, a position from outside the main figures and groupings that determine constructions of cultural memory in a certain generation of writers. Only a few women writers of each generation are placed outside the gendered category of 'escrita feminina'; the inclusion of a female author into a universal canon of cultural memory thus remains 'exceptional' and only achievable to a limited number of writers, who as "boundary markers of national culture (...) guarantee the unity of collective national consciousness" (Owen/Pazos Alonso 2011: 21).

Despite the prevalence of fixed and limiting bracketing of women writers within a national critical context, a counter-memory of alternative categorizations of contemporary female authorship in Portugal also exists. German cultural historian Aleida Assmann ${ }^{3}$ theorises that a cultural memory of the oppressed does not simply disappear, but is kept in a nation's 'memory store', which constitutes a much wider memory base that will be accessed once political restrictions are removed: "in 'functional memory' a political claim is manifest (...) the 'memory store' is its counterpart with its various perspectives on cultural memory (...) [it is] the outer horizon [of functional memory], from which the past's limited perspectives can be relativized, criticised, and ultimately changed" (Assmann 2010: 140-1). New categorizations of female authorship become possible through an interaction with other literary spaces and cultures in feminist and female memory spaces that do not replicate the essentialist limitations of the national canon. Pascale Casanova talks in The World Republic of Letters about the existence of a world literary space, where national literatures are pitched against each other and literary value is not a stable constant but waxes and wanes with the passing of time: "it is therefore necessary to show how the emergence of literary time led to the creation of a literary space endowed with its own laws. This space may be said to be 'inter-national'" (Casanova 2007: 350-1). Authors are valued differently, if their texts are 'translated' into another cultural field. Once author and text leave the national space, critical reception and evaluation by a different 'valuing community' of cultural critics from abroad creates differing 'regimes of value', which often give the text other interpretations. 
This can be seen in a widening of the classificatory categories into which women's writing is placed, as well as the generational connections made between texts and writers. Gender critical content in texts by Lídia Jorge or Inês Pedrosa is never recognized as a critical category and only emerges from a wider, international reception. Lídia Jorge's Notícia da cidade silvestre is never included into the canon of works mentioned in connection with the author, despite the prominent position Jorge's other novels occupy in both Carlos Reis' and Oscar Lopes' / Fátima Marinho's literary histories. This is attributed to the fact that the novel, more than any others Jorge has written, "se deixa envolver com a temática da mulher". 4 Too open a discussion about 'female' or 'feminist' issues only left blank spaces of omission in the national canon. But this is not to say that the novel and its gender critical content left no traces in critical discourse formation on contemporary Portuguese writing. Critical texts written outside the Portuguese cultural field, do engage with Notícia da cidade silvestre in a way that notes the text's criticism of femininity and masculinity in 1970s Portuguese society. Hilary Owen remarks in her book Portuguese Women's Writing, in a chapter dedicated to Lídia Jorge's Notícia da cidade Silvestre, “Jorge makes a gendered point of entry to the subject [critique of colonial historicist epistemologies] focusing on women's relationships to power and violence" (Owen 2000: 93). While Cláudia Pazos Alonso attests in a special edition of Portuguese Literary \& Cultural Studies, which exclusively focuses on Jorge's work, that "in choosing to cast Júlia as her unlikely heroine, Lídia Jorge is making a truly outstanding contribution to the ongoing gender debate in Portugal” (Pazos Alonso 1999: 45). A Brazilian blogger on the feminist forum blogueirasfeministas creates his/her own meta-narrative, re-inventing or readjusting critical classifications in a feminist re-appropriation of Lídia Jorge's novel. The Brazilian blogger emphasises the political connotations of Notícia da cidade silvestre ${ }^{5}$ linking it to the revolutionary spirit of 1974 manifest in the blog in a 'call to arms' of a new revolution guaranteeing women's rights. Although the novel recalls events and circumstances present in Portugal in the 1970s, the feminist blogger uses its content and protagonists to criticise the societal ills of present day Brazil, such as violence against women and the sex industry. The suppression and omission of Notícia da cidade silvestre 
from the national critical context is counter-acted in a global digital memory space, where the novel (and its heroines) metamorphoses into a political metaphor.

Certain aspects of female authors' texts such as the discussion of 'feminist' issues such as abortion, violence against women, economic dependencies of women on men, and non-normative sexualities are persistently ignored and never appear in a national critical discussion, as there are simply no critical spaces into which these themes would fit. In $A s$ herdeiras do segredo Portuguese academic Deolinda Adão, who works at Berkeley in the US, employs categorizations that transgress traditional boundaries in her interpretation of two short stories by Inês Pedrosa and Lídia Jorge. Inês Pedrosa's name is hard to find in literary histories and those who do include her, describe her writing under the category of 'women's writing' with a thematic focus dominated by sensual emotivity: "mundos dispares, (...) femininos, são os de Inês Pedrosa (...) mundo de instrucção sobre os afectos e o amor" (Lopes/Marinho, 2002: 533). Lídia Jorge, usually prominently placed, is primarily discussed as a historic novelist, "um caso paradigmáico da ficcionalização da História" (idem: 466), though her literary consciousness and thematization of historical events is also linked to her gender: "essa incursão [pela guerra colonial] se conjuga habilmente com a problematização da condicão da mulher" (Reis 2006: 302). Adão, in her interpretation of Pedrosa's and Jorge's work, not only moves away from the concept of the 'great novel' that defines the author in choosing two short stories as examples of aspects of their writing, she also draws some generational connections, expressing (gender) political motivations between the writers. Adão writes about Pedrosa: “[a autora] aborda temas problemáticos na sociedade, como a discriminação e a violência doméstica, tema central do conto 'A Cabeleireira"', and she links the short story thematically to Jorge: "ao contrapor ao conto de Pedrosa o conto 'O Marido' de Lídia Jorge, que gira em torno do mesmo tema, mas com um desfecho oposto ao texto de Pedrosa (...) ambos os contos denunciam a proliferação da violência doméstica na sociedade portuguesa" (Adão 2013: 18). A piece of writing that denounces violence against women becomes, in Adão's critical view, a common denominator for many contemporary texts written in Portugal reflecting the legal and political realities in the country: "o problema da violência doméstica assume grave relevo 
em Portugal - essa gravidade aparece refletida em várias obras de ficção (...)"(idem: 22). In a world literary space, as in the blogosphere, a feminist cultural memory becomes possible, as the ideological parameters that determine (and limit) national discourse construction are removed. Traditional categorizations that seem deeply engrained in the critical system are undone and superseded once a global dimension is added.

\section{Performative Strategies in the Press and Author's 'Screen Selves'}

It is not only through the 'translation' of text and author into a world literary space that a (national) critical language is subverted, authors themselves also take part in this process of undoing linguistic normativity in "performativity [which] must be understood not as a singular 'act' but, rather, as the citational practice by which discourse produces the effects it names" (Butler 1993: 2). Constructions of prestige become more multi-layered and open-ended once the presupposed 'autonomy' of the literary establishment, prevalent in academic literary criticism, is subjected to the more commercially orientated and fluid constructions that govern press and online literary criticism, where judgments of cultural value are constantly overwritten and redrawn. "Instead of fixed inscription now there are cascades of images and rivers of information" (Assmann 2010: 212) in press publications that are published daily, weekly or monthly and increasingly also on digital media, where "anyone can say anything" (Myers 2010: 126). In the press the localities into which cultural memory is inscribed are negotiable parameters and testimony to the power relations between press institutionalism, manifest in editorial policies, authorial interventions and market strategies that seek to 'entertain' the readership in order to ensure as wide a circulation as possible. Internet memory spaces are multidirectional, non-linear, nonhierarchical and non-fixed constructions that wax and wane with the interest of their users. They are created by "a large group of people (...) as a collective work whose value far exceeds that provided by any individual participant" (Keen in Bauerlein, 2011: 231). The more fluid and open constructions of cultural value construction online as well as in the press allow cultural memory to be influenced by authors themselves, as they can now enter into the construction of critical metatext on their own work. 
Hélia Correia, in her interventions in the national press, questions the linguistic normativity inscribed in the constructions of the female artist through a performative strategy that tries to overcome the incompatibility between artistic genius and the female condition. Correia achieves this, in the first instance, through a visual performativity, where "the image is immediate expression of an emotion or the unconscious" (Assmann 2010: 220). The photographs that accompany many press publications quite clearly convey a distinct 'persona'. Hélia Correia is dressed in black, or standing outside in ancient woodland, often she is shown holding a cat. These are all images that challenge more traditional portrayals of female authorship, which are often characterized by an interest in the author's appearance (Xavier, 1999 on Lídia Jorge), her role as mother (Jornal de Letras, 1998 on Inês Pedrosa); or domestic arrangements (Martins, 1988 on Lídia Jorge) by primordial means that circumvent and undermine the normativity inscribed in language. The visual performative act is underlined and reinforced by the text (in many instances interviews), where a discourse of fairies, Celtic mythology and feline characteristics (Fiadeiro 1992; Nunes 1996; Nunes 2001; Nunes 2010; Ribeiro 2010) points to cultural and literary spaces outside Correia's own national tradition and questions, even ridicules, preconceived constructions of gender normativity. Christine Battersby writes in Gender and Genius that "the genius was a male (...) who transcended his biology. A woman who created was forced with a double bind: either to surrender her sexuality (becoming not masculine, but a surrogate male), or to be feminine and female, and hence fail to count as genius" (Battersby 1994: 5). Hélia Correia overcomes this double bind in transcending the delimitations ascribed to her sex and superseding the male/female dichotomy by describing herself as 'tipo bicho': "gosto muito pouco de luz (...) durmo mesmo tipo bicho, como os gatos (...)" (Fiadeiro 1992: 60). This is most clearly reflected in an interview in Público after the release of Correia's novel Adoecer, which thematises the muteness of the female muse and the misconceptions surrounding female genius in the $19^{\text {th }}$ century that persist to this day. Raquel Ribeiro entitles the piece 'Hélia Correia é o gato da casa nesta história de amor', which sets the tone for the interview in which Correia firmly refuses the idea that a woman's creativity should be ruled by her gender (Ribeiro 2010: 7). She says of 
her heroine Lizzie Siddal "não, Lizzie é sempre selvagem" (idem: 10), pointing to the fact that only once women are freed from their traditionally passive roles that new inscriptions can be possible for the female artist and a "rematerialization (...) in which the force of the regulatory law can be turned against itself" (Butler 1993: 2) will produce contextualizations, where new female memory spaces are opened up for women artists.

Digital media have added another locality of cultural memory construction, where symbolic value creation resists any totalizing attempts of historicising literature and categorizations of literature and art, building new forms of memory communities created around the popularity and interconnectivity of a particular website, blog or Facebook page. There are no traditional credentials needed to join online memory communities and digital memory spaces offer many opportunities to authors in terms of the image they want to relate to their audiences. Niamh Thornton writes "this is to differentiate between the often invisible presence of a fiction writer, as opposed to the online self-characterisation that takes place through the web, blogging and social media. Here the conceptualisation of self is important'.6 Gender identity is an ambiguous construct in an online world where the 'veil of the screen' enables "online diarists and bloggers [to] use their writing as a mirror that allows them to see themselves more clearly and to construct themselves as subjects in a digital society, but also as a veil that will always conceal much of their lives from their readers".7 Authors, through their own online interventions, can undo or re-enforce critical commentary that would place them in a certain (gendered) category, redrawing the lines of critical metatext, often also in 'interlinking' their websites or Facebook pages to other online critical content they condone.

The difficulties of establishing a feminist cultural memory online has been discussed by various critics such as US writer Amanda Filipacchi, ${ }^{8}$ journalist Noam Cohen ${ }^{9}$ or academic Deanna Zandt, ${ }^{10}$ who all point to the hierarchical institutionalism inherent in the powerful major players on the Internet, like Google or Wikipedia, who re-establish a traditional patriarchal socio-historical discourse in a $21^{\text {st }}$ century guise. But through the 'interlinkage' of online knowledge, digital memory spaces provide infinite variations of memory spaces and an abundant opportunity for the creation of a cultural counter- 
memory. Despite the mechanisms of filtering, supplied by companies like Google, social media, blogs or websites can also create cultural impact through their relational aspect, creating (political) interest communities: "the way we measure influence (...) must also change. Less important are sheer numbers, and more important are measurements of relationships, analysis of what makes particular pieces of content more prone to sharing, and how a person's place in the social network ecosystem affects the sharing that does take place" (Zandt 2010: 60). Social media's discourse construction is constituted by a string of conversations. Authors, who, after all, are experts in telling stories, can now skillfully exploit which 'story' emerges from a multidirectional dialogue. Through the online platform discussions, which, offline, would be conducted by groups of friends in cafes and living rooms, can now be magnified and reach a global audience of others interested in the topics that appear in posts, videos, etc. And although it is Wikipedia's page that first comes up in a Google search for an author's name, it is literary blogs and Facebook pages that specifically target groups of people who might be interested in the author and her work.

Such a mutual dissemination of cultural comment can be observed between the writer Inês Pedrosa and the blogging book lover Vera Helena Sopa. Vera Helena Sopa dedicates two reviews to Inês Pedrosa's work on her blog Ler, um prazer adquirido. She tells her readers precisely why she is so fond of the author: "[Desamparo é um livro] despretensioso e bem escrito, como eu gosto. Visualizo os lugares e as pessoas nas palavras de Inês Pedrosa (...). [Dentro de Ti Ver o Mar é] Bem dimensionado, fácil de manusear (...). Mais uma vez as personagens femininas cativaram-me (...). Uma agradável leitura".11 And the author herself makes use of the blog's popularity and readership by posting a comment on her Facebook site about Sopa's review. ${ }^{12}$ She is not only giving the blogger some prominent exposure but also ascribing critical value to the subjective views expressed by the female blogger whose only qualification for such cultural comment is her love of reading: "Ler foi um aprendizado adquirido em criança que se tornou um prazer nos tempos livres. Sonhar e divagar sem sair do lugar".13 For authors, exposure on a blog can signify a more important gain in readership than an interview in a cultural magazine, not least, because the readers of the blog form part of a community that shares interests also 
represented in the text that is reviewed, which has already been selected by the blogger as being 'worth reading'. A greater readership might, in a first instance result in greater sales for a new title (most book blogs are also heavily linked in with publishers, which can be directly accessed through the blog). For the blogger Pedrosa's post on her Facebook site adds authorial credentials to her literary comments, and both women are mutually increasing their readership and prestige. Such female memory communities do by no means occupy marginal spaces in the online knowledge economy, Sopa's blog has had over 50,000 visitors (or 'hits') since 2011, magnified through the blogger's presence on Facebook and the favorable recommendations she receives from other bloggers. Pedrosa's Facebook site is hugely popular with over 4,000 likes and is linked in with the author's Twitter account (nearly 14,000 followers) and website.

An example of an inscription into a global (feminist) critical metatext can be seen in an interplay between Teolinda Gersão, a translation of her short story The Woman Who Stole the Rain by Margaret Jull Costa posted on the Internet literary forum WordsWithoutBorders ${ }^{14}$ and a blog post by Kinna from Ghana, whose reviews focus on feminist writing around the world. Kinna writes that she is "a lifelong reader, lover of all things literary. I read mostly fiction. I enjoy world literature. I'm partial to women writers", 15 and she comments on the story, which she picked up in its English translation. There is a clear political interest in Kinna's blog and she is consciously introducing Gersão to her readers as a writer "the system works really hard to hide", 16 also picking up on the societal critique the story represents: "the woman's grief had stolen the rain (...); she is betrayed by a society that in its inability to console, cannot tolerate her company". ${ }^{17}$ Kinna's blog is hugely popular, with nearly 200,000 hits in the last three years and it is not surprising that her post on Gersão creates great interest in the online community reading her blog. Comments are not all favourable, but there is a clear sense of readers being interested in Gersão and her work, as a writer they had never heard about before. Teolinda Gersão herself joins the conversation in English, thanking for all the interest in her work, and also promoting the release of The Word Tree, which was shortly to be published in English. Kinna's comments inspire other bloggers from the US and Canada 18 to write about 
The Woman Who Stole the Rain, which they contextualize as an example of international women's writing.

In both instances, Inês Pedrosa and Teolinda Gersão themselves condone the critical categories into which they had been inscribed by the bloggers, creating their own contextualizations of their work, as well as establishing an (online) interest community round the issues discussed in the texts. This counter-memory to the national critical context is replicated, interlinked, re-tweeted etc. into an online global memory space, where memory spaces do not offer a final or finite version of history; they "are (...) constantly open to revision" (Myers 2010: 66), they are "creating sustainable relationships across which content flows many ways" (Zandt 2010: 67). In this sense, the authorial self that is replicated in such knowledge spaces constitutes an anti-memory to the critical context displayed in national print media: "it sustains an official counter memory, which is a critical subversive memory (...) a delegitimization" (Assmann 2010: 138) from which new critical contextualizations can be formed.

\section{Conclusion}

A gender specific representation of female authorship can certainly be observed in academic literary criticism, and in press as well as online discourse, but, at the same time new classificatory categories are also emerging. And although a female or feminist cultural memory often represents a heritage that has been "betrayed, misplaced, given away and sold" (Assmann 2010: 122), there is also a hope that future generations will "know the past, and know it differently" (Rich 1980: 35). I hope that in this article I have shown that, despite the still existing considerable obstacles and prejudices of literary criticism in Portugal, the possibility of an emerging of different generational contextualizations in press and online criticism that would enable the creation of new classificatory categories more adequately representative of contemporary female authorship. Press dialogue and online diversification of cultural memory have provided Lídia Jorge, Teolinda Gersão, Hélia Correia and Inês Pedrosa, with increasing opportunities to communicate with readers and critics 
alike, and therefore influencing the critical reception of their own work, while, in the case of digital media, the critical discourse has been opened up to anyone who cares to participate. Tentative attempts at creating new categorizations for female authorship in the press together with the web's 'grass-root' criticism enables the establishment of different ways in which to construct the cultural memory of female authors and their texts and the creation of new memory communities, defying those established by traditional criticism. The role of the critic, as gatekeeper of literary or cultural knowledge has been usurped by a far wider pool of cultural commentators, but whether this wider critical meta-text will indeed lead to the construction of a female tradition in Portuguese literary history and critical classifications free from a gender bias, only future developments can tell.

\section{NOTES}

${ }^{1}$ I refer to female memory spaces as localities of cultural memory that do not conform with the dominant, traditional critical view that equates the male with the universal. Female memory spaces can be found in criticism that inscribes women writers into a universal literary heritage rather than essentialist, gendered categories. Feminist memory spaces are distinguished through an ideological outlook in a political sense. Here the critical commentary on the author and her work is linked to a political message.

${ }^{2}$ I use the term 'performative acts' in the sense that Judith Butler cites as "gender is the repeated stylization of the body, a set of repeated acts (...) [which] are performative in the sense that the essence or identity that they otherwise purport to express are fabrications (...)" $(2007: 33,136)$.

${ }^{3}$ Translations from German are mine.

${ }^{4}$ See http://www.portaldaliteratura.com/livros.php?livro=836.

${ }^{5}$ See http://blogueirasfeministas.com/2012/01/lidia-jorge/. 
${ }^{6}$ See http://interamericaonline.org/volume-5-1/thornton/.

${ }^{7}$ See http://interamericaonline.org/volume-5-1/thornton/.

8 See http://www.nytimes.com/2013/04/28/opinion/sunday/wikipedias-sexism-toward-femalenovelists.html?_r=0.

${ }^{9}$ See http://www.nytimes.com/2011/01/31/business/media/31link.html.

${ }^{10}$ See http://www.forbes.com/sites/deannazandt/2013/04/26/yes-wikipedia-is-sexist-thats-why-it-needsyou/.

${ }^{11}$ See http://lerprazeradquirido.blogspot.co.uk.

${ }^{12}$ See https://www.facebook.com/inespedrosa.oficial, 21/06/2015.

${ }^{13}$ See http://lerprazeradquirido.blogspot.co.uk.

${ }^{14}$ See http://www.wordswithoutborders.org/article/the-woman-who-stole-the-rain.

${ }^{15}$ See https://kinnareads.com/about/.

${ }^{16}$ See http://kinnareads.wordpress.com/2011/08/22/the-woman-who-stole-the-rain-by-teolinda-gersao/.

${ }^{17}$ http://kinnareads.wordpress.com/2011/08/22/the-woman-who-stole-the-rain-by-teolinda-gersao/.

${ }^{18}$ See https://theeclecticreader.wordpress.com/2011/09/19/review-the-woman-who-stole-the-rain-byteolinda-gersao-short-story/, and http://teddyrose.blogspot.co.uk/2012/01/woman-who-stole-rain-byteolinda-gersao.html. 


\section{Works Cited}

Adão, Deolinda (2013), As herdeiras do segredo: personagens femininas na ficção de Inês Pedrosa, Texto Editores, Alfragide.

Assmann, Aleida (2010), Erinnerungsräume: Formen und Wandlungen des kulturellen Gedächtnisses, C.H. Beck, Munich.

Battersby, Christine (1994), Gender and Genius: Towards a Feminist Aesthetics, The Women's Press Ltd., London.

Bauerlein, Mark (2011), The Digital Divide, Jeremy P. Tarcher/Penguin, New York.

Blogueirasfeministas (2013), As mulheres de Lídia Jorge: Notícias da Cidade Silvestre, <http://blogueirasfeministas.com/2012/01/lidia-jorge/> (accessed 07 October 2015).

Butler, Judith (1993), Bodies That Matter: On the Discursive Limits of "Sex", Routledge, New York.

-- (2007), Gender Trouble: Feminism and the Subversion of Identity, Routledge, New York.

Carolina (2011), "Review: The Woman Who Stole the Rain by Teolinda Gersão (Short Story)", Eclectic Book Readings, blog, <https://theeclecticreader.wordpress.com/ 2011/09/19/review-the-woman-who-stole-the-rain-by-teolinda-gersao-short-story/> (accessed 27 November 2016).

Casanova, Pascale (2007), The World Republic of Letters, Harvard University Press, Cambridge/Massachusetts.

Cohen, Noam (2011), “Define Gender Gap? Look Up Wikipedia's Contributor List”, New York Times, 30 January, <http://www.nytimes.com/2011/01/31/business/media/31link.html> (accessed 27 November 2016).

Edfeldt, Chatarina (2006), Uma história na História: Representações da autoria feminine na História da Literatura Portuguesa do século XX, Câmara Municipal de Montijo, Montijo. 
Frow, John (1995), Cultural Studies and Cultural Value, Oxford, Oxford University Press.

Fiadeiro, Maria Antónia (1992), "Hélia Correia: A casa eterna, vencedor do Prémio Máxima de literatura", Máxima, May, 59-63.

Filipacchi, Amanda (2013), “Wikipedia's Sexism Toward Female Novelists”, The New York Times, 24 January, <http://www.nytimes.com/2013/04/28/opinion/sunday/wikipediassexism-toward-female-novelists.html? $r=0>$ (accessed, 27 November 2016).

Jornal de Letras (1998), “Inês Pedrosa: mãe de Laura”, Jornal de Letras, 28 January, 5.

Jull Costa, Margaret (2007), “The Woman Who Stole the Rain" by Teolinda Gersão (translation), WordsWithoutBorders: The Online Magazine for International Lierature, <http://www.wordswithoutborders.org/article/the-woman-who-stole-the-rain> (accessed, 27 November 2016).

Kinna Reads (2011), “The Woman Who Stole the Rain by Teolinda Gersão”, Kinna Reads: A blog of books, reading and world literature, <http://kinnareads.wordpress.com/ 2011/08/22/the-woman-who-stole-the-rain-by-teolinda-gersao/> (accessed on 07 October 2013).

Lopes, Óscar /Maria de Fátima Marinho (eds.) (2002), História da Literatura Portuguesa, Vol. 7: As correntes contemporâneas, Publicações Alfa, Lisboa.

Macedo, Ana Gabriela/ Amaral, Ana Luísa (2002), “A Palavra, a Identidade e a Cultura Translativa: para uma Introdução do Dicionário Terminológico de Conceitos da Crítica Feminista", in Maria Irene Ramalho, António Sousa Ribeiro (eds.). Entre Ser e Estar: Percursos e Discursos de Identidade, Edições Afrontamento, Porto, 383-408.

Martins, Luís Almeida (1988), "Lídia Jorge, Notícia do cais dos prodígios”, Jornal de Letras, 15 February, 6-10.

Myers, Greg (2010), Discourse of Blogs and Wikis, Continuum, London.

Nunes, Maria Leonor (1996), “Hélia Correia: a virtude da preguiça”, Jornal de Letras, no 682, 4 December, 13-16. 
-- (2001), “Hélia Correia: no país das fadas”, Jornal de Letras, no 802, 27 June, 11-12.

-- (2010), “Hélia Correia: uma paixão inglesa”, Jornal de Letras, no 1030, 24 March, 10-13.

Owen, Hilary (2000), Portuguese Women's Writing 1972 to 1986. Reincarnations of a Revolution. Lewiston, Queenston, Lampeter: Edwin Mellen.

-- /Pazos Alonso, Cláudia (2011), Antigone's Daughters?: Gender, Genealogy, and the Politics of Authorship in 20th-Century Portuguese Women's Writing, Bucknell University Press, Lewisburg.

Pazos Alonso, Claudia (1999), "Sex and Success in Notícia da Cidade Silvestre: A Tale of Two Cities", Portuguese Literary and Cultural Studies 2, 33-48.

Pedrosa, Inês, "official" Facebook site, <https://www.facebook.com/inespedrosa.oficial>, (accessed 30 April 2016).

Pinto do Amaral, Fernando (2002), 100 Livros Portugueses do Século XX: uma selecção de obras literárias, Instituto Camões, Lisboa.

0 Portal de Literatura, Notícia da Cidade Silvestre (1984), <http://www.portaldaliteratura.com/livros.php?livro=836>, (accessed 27 November 2016).

Reis, Carlos (2006), História Crítica da Literatura Portuguesa, Vol. 9: Do neo-realismo ao pósmodernismo, Editorial Verbo, Lisboa.

Rendeiro, Margarida (2007), The Literary Institution in Portugal since the Thirties: An Analysis under Special Consideration of the Publishing Market, Thesis, Kings College London. Rich, Adrienne (1980), On lies, secrets and silence: selected prose 1966-1978, Virago, London. Ribeiro, Raquel (2010), "Hélia Correia é o gato da casa nesta história de amor", Público, 26 March, 7-11.

Santos/ Maria Irene Ramalho de Sousa /Amaral, Ana Luísa (1997), Sobre a "Escrita Feminina", Centro de Estudos Sociais, Coimbra. 
Sopa Vera, Helena (2015), Ler um prazer adquirido, blog, <http://lerprazeradquirido.blogspot.co.uk>, (accessed 10 October 2015).

Teddy, Rose, The Woman Who Stole the Rain by Teolinda Gersão, teddyrose, blog, <http://teddyrose.blogspot.co.uk/2012/01/woman-who-stole-rain-by-teolindagersao.html> (accessed 27 November 2016).

Thornton, Niamh (2012), "The Fairies at the Bottom of the Garden", Forum for InterAmerican Research, Volume 5, Issue 1, April, online resource, <http://interamericaonline.org/volume-5-1/thornton/> (accessed 27 November 2016).

Xavier, Leonor (1999), 'Lídia Jorge: A reclamação de um amor', Máxima, November.

Zandt, Deanna (2010), Share This!: How You Will Change the World with Social Networking, Berrett- Koehler Publishers, San Francisco.

-- (2013), "Yes, Wikipedia is Sexist-That's Why it Needs You”, Forbeswoman, 26/04/2013, <http://www.forbes.com/fdc/welcome_mjx.shtml> (accessed 27 November 2016).

Suzan Bozkurt has recently completed her $\mathrm{PhD}$ thesis on contemporary Portuguese women's writing, at the University of Manchester under the supervision of Hilary Owen and has published widely on contemporary women's writing in Portugal and translation theory. Her most recent publications are translations and introductions to short stories by Teolinda Gersão and Luísa Costa Gomes and articles on writers Teolinda Gersão and Inês Pedrosa for an online archive for the Centre of Contemporary Women Writers at the IGRS (London). Her research interests are gender studies, digital media and translation theory. 